\title{
Karyotypes and microfluorometric studies in Porphyra columbina Montagne (Bangiales, Rhodophyta), with reference to morphology and sexuality
}

\author{
Cariotipos y estudios microfluorométricos en Porphyra columbina Montagne (Bangiales, \\ Rhodophyta), en relación a morfología y sexualidad
}

\author{
Rodrigo Badilla ${ }^{1}$, Elisabeth Von Brand ${ }^{2}$ and Gloria Collantes ${ }^{1}$ \\ ${ }^{1}$ Facultad de Ciencias del Mar y de Recursos Naturales, Universidad de Valparaíso, Valparaíso \\ Casilla 5080 Reñaca, Viña del Mar, Chile \\ ${ }^{2}$ Departamento de Biología Marina, Facultad de Ciencias del Mar, Universidad Católica del Norte, \\ Casilla 117, Coquimbo, Chile \\ gloria.collantes@uv.cl
}

\begin{abstract}
Resumen.- En la costa central de Chile se han registrado diez morfotipos atribuidos a diferentes especies de Porphyra. En este trabajo informamos del número de cromosomas y resultados de estudios microfluorométricos en gametofitos reproductivos de $P$. columbina. El material fue recolectado en caleta Montemar (3257'S - 71'33’W). Los ejemplares fueron separados en dos morfotipos según morfología, sexualidad y patrón característico de distribución de las células reproductivas masculinas y femeninas: P. columbina (gametofitos monoicos con distribución entremezclada de manchones reproductivos femeninos y masculinos); P. columbina f.1, (gametofitos dioicos o monoicos con distribución sectorizada de manchones reproductivos masculinos y femeninos).

Los resultados obtenidos en $P$. columbina ( $\mathrm{n}=20$ gametofitos) indican un número básico haploide de cromosomas $n=3$, excepto una fronda con 2 y 3 cromosomas en sus células. Los resultados obtenidos en $P$. columbina $\mathrm{f} .1$ ( $\mathrm{n}=26$ gametofitos) demuestran un número haploide de cromosomas $n=4$, pero esta condición no es consistente, algunos gametofitos presentan rangos de número haploide de cromosomas $n=3$ y $n=5$. El promedio de fluorescencia de DNA en células de espermatangios y en células de zigotoesporangios, en ambos morfotipos, presentó valores coherentes para haploidía y diploidía, respectivamente. Comparaciones de valores de fluorescencia de DNA nuclear entre espermatangios de $P$. columbina y $P$. columbina f.1 mostraron diferencias significativas $(P<0,05)$.
\end{abstract}

Palabras clave: Algas rojas, cromosomas, microfluorometría

\begin{abstract}
Ten morphotypes attributed to different species of Porphyra have been found in the central coast from Chile. In this paper we report the chromosome number and microfluorometric studies in P. columbina from Montemar,

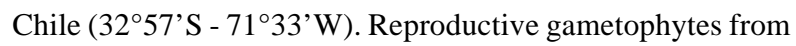
two morphotypes were separated by morphology, sexuality and characteristic pattern distribution of reproductive cells: $P$. columbina (monoecious interspersed male and female patches distribution) and P. columbina f. 1 (dioecious and monoecious sectorised male and female patches distribution).

The results of $P$. columbina ( $\mathrm{n}=20$ gametophytes) showed a basic haploid chromosome number of $n=3$, except one frond with 2 and 3 chromosomes in their cells. The results of $P$. columbina f.1 ( $\mathrm{n}=26$ gametophytes) showed a haploid chromosome number of $n=4$, but the haploid condition was found inconsistently in some fronds, having a chromosome range from 3 to 5. Mean of nuclear DNA fluorescence of spermatangia and zygotosporangia of both morphotypes had coherent haploid and diploid values. Inter morphotypes comparison of nuclear DNA fluorescence values in spermatangia had significant differences $(P<0.05)$.
\end{abstract}

Key words: Red algae, chromosomes, relative fluorescence units

\section{Introduction}

The red algal species Porphyra columbina Montagne is a common component of rocky intertidal habitats in temperate waters of Chile. Dried species of Porphyra ("luche") are used as food. During the last eleven years the total annual average of Porphyra harvest has been estimated to be 16,36 tons (90\% of humidity) (Sernapesca 2005).
Species of Porphyra have traditionally been identified on limited variation of morphological features of the foliose thallus, such as shape, size, color, thickness, sexuality and both macroscopic and microscopic patterns of reproductive cells. Ten morphotypes attributed to different species of Porphyra have been found in the Central coast from Chile (González \& Collantes 2001), one of these P. columbina Montagne has been registered 
under other names such as $P$. columbina f. kunthiana Hamel and P. kunthiana Kutzing (Ramirez \& Santelices 1991). Another similar morphotype has been registered as P. columbina f.1 (González \& Collantes 2001).

In Porphyra, chromosome counts and karyotypes have provided some evidence of species identities (Ishikawa 1921 fide Yabu \& Tokida 1963, Coll \& de Oliveira Filho 1977, Mumford \& Cole 1977, Krishnamurthy 1984, Avila et al. 1986, Kapraun \& Freshwater 1987, Candia et al. 1990, Wilkes et al. 1999). For the same purpose Lindstrom \& Cole (1992a, 1992b) have been also used isozymes, morphology and chromosomes. Karyological studies and cytophotometric estimation of inter and intra specific nuclear DNA variations have been published by Kapraun et al. (1991).

Karyological studies of the gametophyte and conchocelis phases of $P$. columbina from the central Chilean coast showed a haploid chromosome number of $\mathrm{n}=3$ and diploid chromosome numbers of $2 \mathrm{n}=6$ (Candia et al. 1990). These results added $P$. columbina from Chile to the global karyological pattern of 26 species of Porphyra n=3, and 14 species of Porphyra 2n=6 (Yabu 1975, Mumford \& Cole 1977). In this paper, we report the chromosome number and microfluorometric studies in $P$. columbina and $P$. columbina f. 1 with references to morphology, sexuality and characteristic distribution of reproductive patches.

\section{Material and methods}

Twenty gametophytes of $P$. columbina having interspersed female (red) and male (yellow) patches (monoecious) and twenty six gametophytes of $P$. columbina f.1 (dioecious) and having sectorised female (red) and male (yellow) patches (monoecious) (Fig. 1) were collected during 2001 - 2002 from Montemar Cove, Valparaíso Bay, Chile (3257.381' S - 71³3.960' W) (GPS - GARMIN etrex). Voucher specimens were deposited in the Herbario del Museo de Historia Natural, Santiago, Chile (SGO) (P. columbina SGO 155110 and P. columbina f.1 SGO 155111).

For chromosome counts, male reproductive cells were selected from the yellow reproductive patches (spermatangia). The cells were incubated $24 \mathrm{~h}$ in Provasoli medium with $0.5 \%$ colchicine and transferred to 0.075 $\mathrm{M} \mathrm{KCl}$ for $1 \mathrm{~h}$. Material was fixed in 4:1 methanol: glacial acetic acid for $24 \mathrm{~h}$ (Andras et al. 1999) and stored in 70\% ethanol. Chromosomes were stained in Wittmann's haematoxylin (Wittmann 1965), during 1h prior to squash preparation. Chromosome numbers were counted in a
Nikon Labophot microscope equipped with a photographic camera. Measurements and arrangement of chromosomes for karyotype were made using the software Image Pro-Plus 4.1.

For microfluorometric studies, spermatangia and zygotosporangia were previously fixed and stained using $0.5 \mu \mathrm{g} \mathrm{mL}^{-1} \mathrm{DAPI}$, heating in a domestic microwave during 15 seconds (Goff \& Coleman 1987, 1990, Han-Gu et al. 1994). DAPI fluorescence was examined using UV exciter filters to produce peak excitation between 330-380 nm. Observation of nuclear DNA was made using a microscope Nikon Eclipse E-600 equipped with a video camera COHU model 4910 connected to a computer. For measurements of relative fluorescence intensity of DAPI-stained nuclei, images were analyzed using the software Image Pro-Plus 4.1.

The data of DAPI-stained nuclei were recorded and processed with Microsoft Excel. Data were analyzed, using one-way ANOVA $(\alpha=0.05)$ and the statistical software SPSS 11. $\log _{10}(x+1)$ transformations were performed prior to analysis with one-way ANOVA and then tested with a test of homogeneity of variances (Levine's test). Untransformed data are presented in figures and tables.

\section{Results and discussion}

The haploid number of chromosomes found in $P$. columbina was $n=3$, except one frond with 2 and 3 chromosomes in their cells (Fig. 2a). The haploid number of chromosomes found in $P$. columbina $\mathrm{f} .1$ was $\mathrm{n}=4$, but in some of the fronds chromosome ranged from $n=3$ to $\mathrm{n}=5$, (Fig. $2 \mathrm{~b}$ and 3).

Mean of nuclear DNA fluorescence of spermatangia and zgotosposporangia had coherent values in both morphotypes, showing haploid cells and diploid cells respectively. Intermorphotype comparison of nuclear DNA fluorescence values in spermatangia showed significant differences $(P<0.05)$ (Tables 1 and 2$)$. The two morphotypes had monostromatic blades and similar shape, but $P$. columbina f.1 was dioecious (Fig. 1a, b) and monoecious (sectorised male and female patches) (Fig. 1c) whereas $P$. columbina was always monoecious (interspersed male and female patches) (Fig. 1d).

The fluorescence intensity reported for both morphotypes was related with the observed chromosome number. The standard deviation (SD) of the relative fluorescence intensity of $P$. columbina $(\mathrm{n}=3)$ was 101.64 , and for $P$. columbina f.1 ( $\mathrm{n}=4, \mathrm{n}=3$ and $\mathrm{n}=5)$ was higher, 154.61 (Table 1). The two methods employed have been 

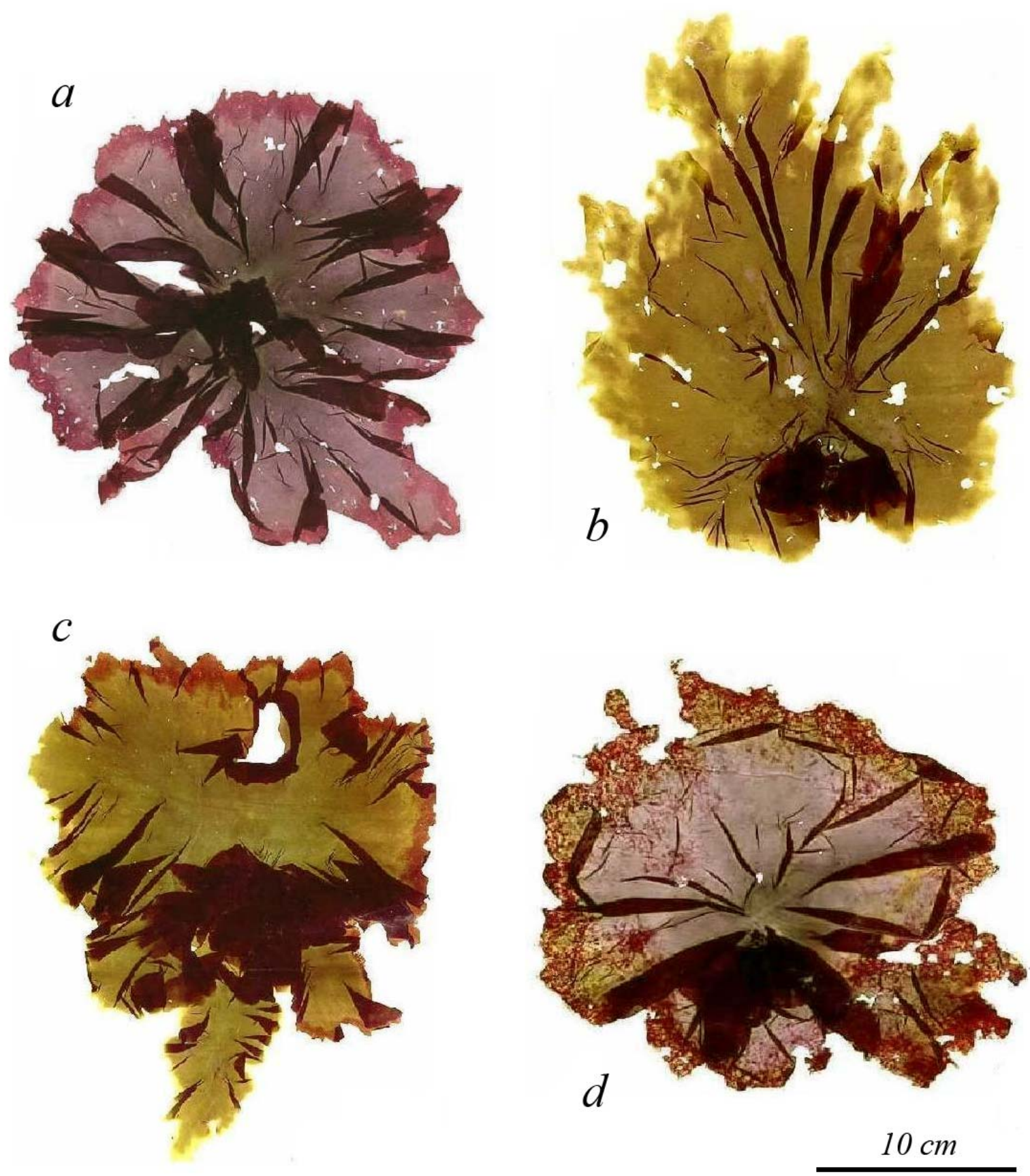

Figure 1

Morphology and characteristic distribution of reproductive patches in $P$. columbina and $P$. columbina f.1: a) $P$. columbina f.1, dioecious female frond, b) $P$. columbina f.1, dioecious male frond, c) $P$. columbina f.1, monoecious frond d) $P$. columbina, monoecious frond

Morfología y distribución característica de manchones reproductivos en $P$. columbina and $P$. columbina f.1: a) $P$. columbina f.1, fronda femenina dioica, b) P. columbina f.1, fronda masculina dioica, c) P. columbina f.1, fronda monoica, d) P. columbina, fronda monoica 


\section{Table 1}

$P$. columbina and $P$. columbina f.1. Number of nuclei $(\mathrm{N})$, values of relative fluorescence intensity (mean and standard deviation) and ploidy levels

$P$. columbina y $P$. columbina f.1. Número de núcleos (N), valores de intensidad relative de fluorescencia (media y desviación estándar) y niveles de ploidía

\begin{tabular}{ccccc}
\hline & N & Mean & $\begin{array}{c}\text { Standard } \\
\text { deviation }\end{array}$ & Ploidy \\
\hline Porphyra columbina & & & & \\
Spermatia & 582 & 258.88 & 101.64 & $\mathrm{n}$ \\
Carpospores & 342 & 576.90 & 162.11 & $2 \mathrm{n}$ \\
Porphyra columbina f.1 & & & & \\
Spermatia & 21650 & 421.69 & 154.61 & $\mathrm{n}$ \\
Carpospores & 12100 & 948.69 & 335.74 & $2 \mathrm{n}$ \\
\hline
\end{tabular}

Table 2

$P$. columbina and $P$. columbina f.1. Comparisons of relative nuclear DNA contents of spermatangia, One-way ANOVA test $(\alpha=0.05)$

P. columbina y P. columbina f.1. Comparaciones de contenido de ADN nuclear de células de espermatangios. Prueba ANOVA una vía $(\alpha=0,05)$

\begin{tabular}{lcccccc}
\hline & $\begin{array}{r}\text { Sum of } \\
\text { squares }\end{array}$ & $\begin{array}{c}\text { Degree of } \\
\text { freedom }\end{array}$ & Mean square & F & p-level \\
Pc-Pc f.1 & 25.548 & 1 & 25.548 & 721.622 & 0.000 \\
\hline
\end{tabular}

complementary used in Porphyra studies by Kapraun et al. (1991).

$P$. columbina and $P$. columbina $\mathrm{f} .1$ showed differences in frequency and percentage of the chromosome number (Table 3, Fig. 4). The higher percentage of both species represents the chromosome number assigned to each morphotype. The increase or decrease of this last number by one chromosome found in P. columbina f.1 can be explained by aneuploidy effect (Jackson 1971) what seems to be widespread in algae (Godward 1966). Aneuploidy is considered as a sign of speciation in plants and animals (Ayala \& Kiger 1984). Candia et al. (1990) discussed aneuploidy in morphotypes of the P. columbina system from Central Chile; two of these $P$. columbina morphotypes showed in the same plant spermatangia cells with $n=3, n=4$ and $n=5$, although these authors did not describe the morphological characteristics nor reproductive patterns of the two mentioned morphotypes.

The histograms of $P$. columbina and $P$. columbina $\mathrm{f} .1$

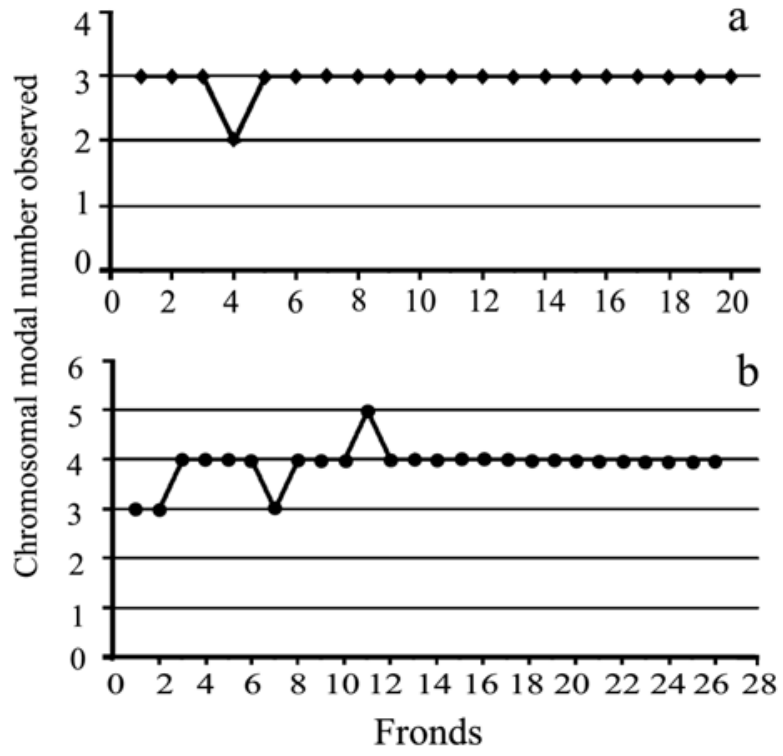

Figure 2

Modal chromosome number in: a) $P$. columbina and b) $P$. columbina f.1

Número modal de cromosomas en: a) $P$. columbina y b) P. columbina f.1

Table 3

P. columbina (Pc) and P. columbina f.1 (Pc f.1). Frequency $(\mathrm{N})$ and percentage $(\%)$ of the chromosome number in each plate in spermatangia

P. columbina (Pc) y P. columbina f.1. Frecuencia (N) y porcentaje (\%) del número de cromosomas en cada placa de espermatangios

\begin{tabular}{lcrr}
\hline Species & $\begin{array}{c}\text { Chromosome } \\
\text { number in each plate }\end{array}$ & N & $\%$ \\
\hline Porphyra columbina & 2 & 33 & 7.3 \\
& 3 & 419 & 92.7 \\
Porphyra columbina $\mathrm{f} .1$ & 3 & 157 & 23.3 \\
& 4 & 411 & 60.8 \\
& 5 & 107 & 15.8 \\
\hline
\end{tabular}

(monoecious and dioecious) (Fig. 4a and 4b) and $P$. columbina f.1 (monoecious) and $P$. columbina f.1 (dioecious ) (Fig. 4c and 4d) showed chromosome numbers in metaphase plates of spermatangia cells, both having different chromosome numbers. In P columbina f.1 there were not significant differences in the chromosome numbers of both monoecious and dioecious fronds $(P>0.05$ ), both having similar histograms (Fig. 4c and $4 d)$. 


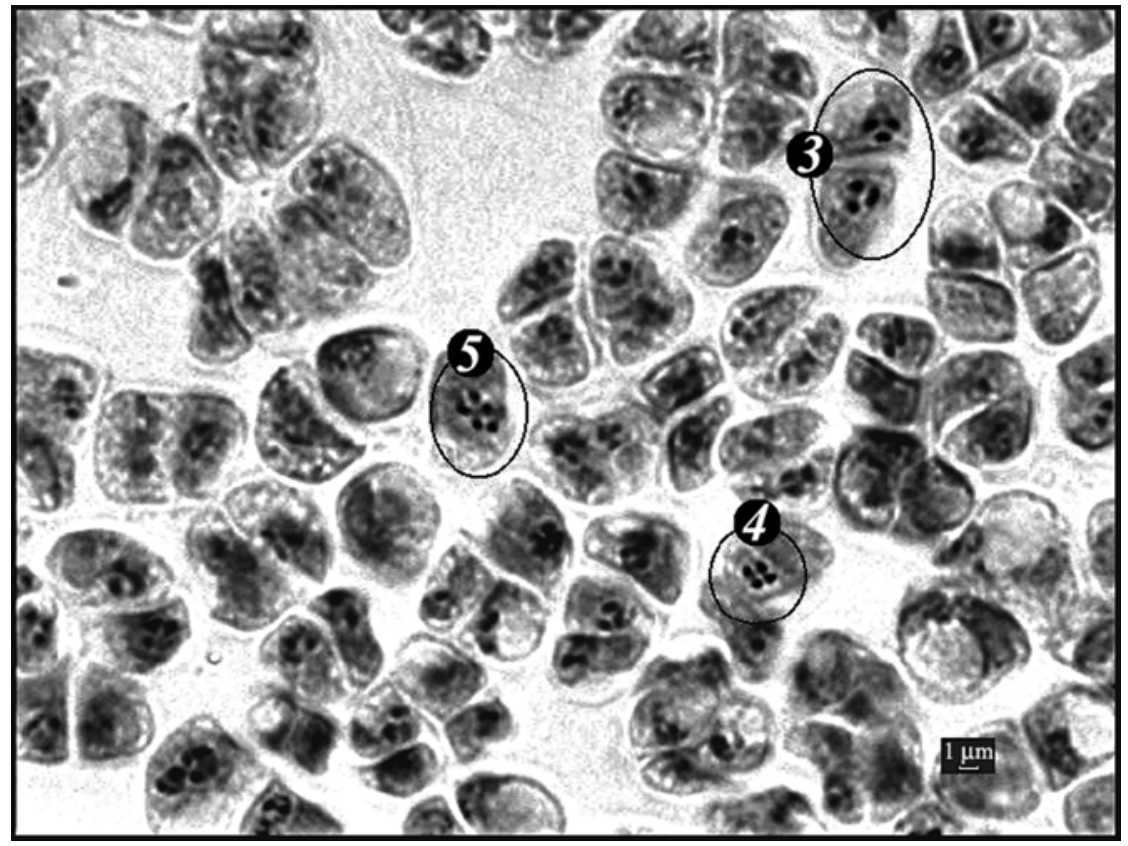

Figure 3

P. columbina f.1. Spermatia cells showing different haploid chromosome numbers. Circles show the number of chromosomes

P. columbina f.1. Células de espermatangios mostrando diferentes números haploides de cromosomas. Los círculos destacan el número de cromosomas

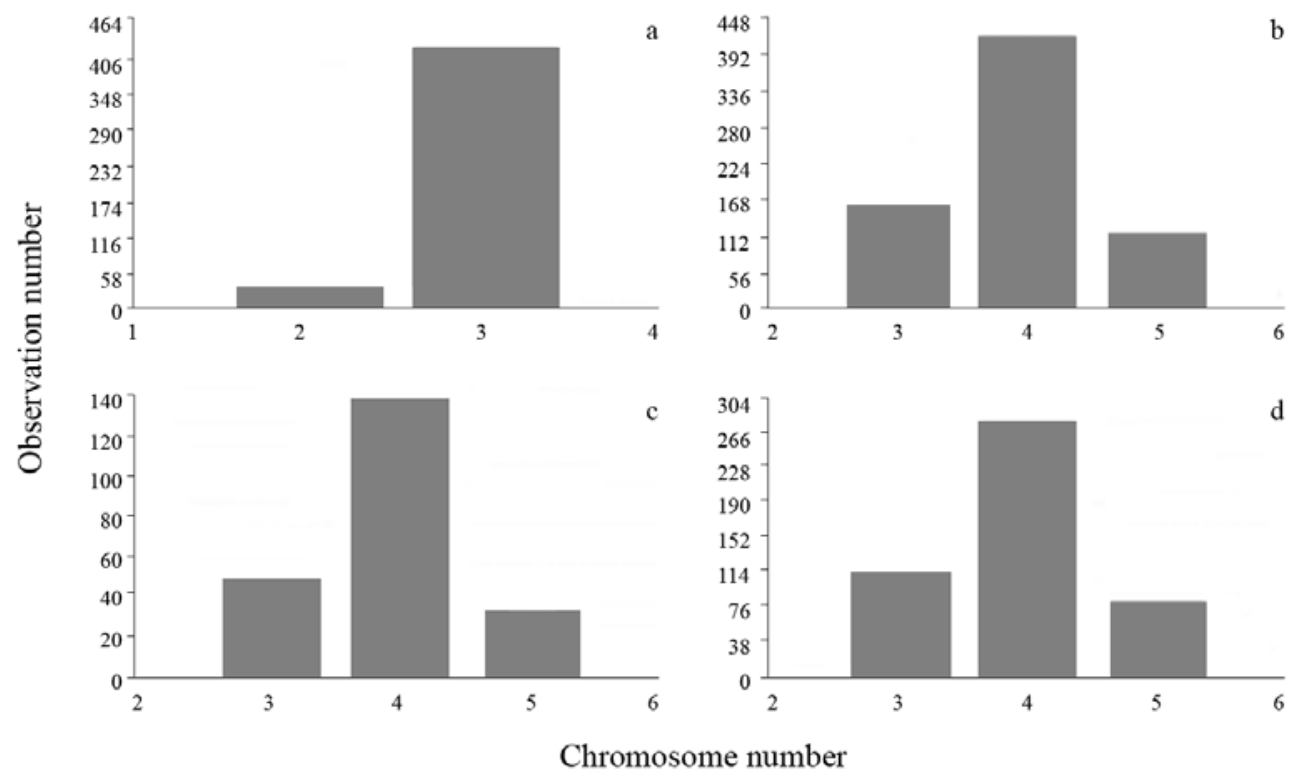

Figure 4

Histograms of the chromosome numbers in: a) $P$. columbina; b) $P$. columbina f.1 (monoecious and dioecious); c) P. columbina f.1 (monoecious); d) P. columbina f.1 (dioecious)

Histogramas con número de cromosomas en: a) P. columbina; b) P. columbina f.1 (monoico y dioico); c) $P$. columbina f.1 monoico; d) P. columbina f.1 dioico 


\section{$1 \mu \mathrm{m} \underline{\mathrm{CO}} \quad$ P. columbina $\mathrm{n}=3$ \\ $1 \mu \mathrm{m}$ \\ $1 \mu \mathrm{m}$ P. columbina $\mathrm{f} .1 \mathrm{n}=3$ \\ $1 \mu \mathrm{m}$}

Figure 5

Haploid karyotypes from $P$. columbina $(n=3)$,

$P$. columbina f.1 $(n=4)$ and the variation in

$P$. columbina f.1 ( $n=3$ and $n=5)$

Cariotipos haploides de $P$. columbina $(\mathrm{n}=3), P$. columbina

f.1 $(n=4)$ y la variación en $P$. columbina f. $1(n=3$ y n=5)

Karyotypes of $P$. columbina and P. columbina f.1 showed the characteristic arrangement, shape and size of the Porphyra chromosomes (Fig. 5). According to Mumford \& Cole (1977) the observed chromosomes of $P$. columbina and $P$. columbina $\mathrm{f} .1$ can be classified as short $(0.5-1.0 \mu \mathrm{m})$ and medium $(1.0-2.5 \mu \mathrm{m})$.

Our data show that $P$. columbina and P. columbina f.1 differ in the distribution of reproductive patches, haploid chromosome numbers and relative fluorescence intensity. Additionally, number and distribution of chromosomes in monoecious and dioecious fronds of $P$. columbina f.1 give evidence belonging to a single morphotype. These results indicate that $P$. columbina and $P$. columbina f.1 morphotypes are different species.

\section{Acknowledgments}

We thank specially to the working group of the Laboratorio de Genética, Universidad Católica del Norte. We also thank two external referees for their comments that improved the style of this manuscript. Financial support by DIPUV 29-2000 to G. C.

\section{Literature cited}

Andras SC, TPV Hartman, JA Marshall, R Marchant, JB Power, EC Cocking \& MR Davey. 1999. A drop-spreading technique to produce cytoplasm-free mitotic preparations from plants with small chromosomes. Chromosome Research 7: 641-647.

Avila M, B Santelices \& J McLachlan. 1986. Photoperiod and temperature regulation of the life history of Porphyra columbina (Rhodophyta, Bangiales) from central Chile. Canadian Journal of Botany 64: 1867-1872.
Ayala FJ \& J Kiger. 1984. Genética Moderna, 836 pp. Fondo Educativo Interamericano, México.

Candia A, M Cordeiro-Marino \& E Reyes. 1990. Estudios cariológicos en Porphyra columbina Agardh I. Número de cromosomas en fases de Porphyra columbina Montagne (Bangiales, Rhodophyta). Hoehnea 17(1): 91-97.

Choi H-G, YK Lee \& K Lee. 1994. Measurement of DAPIstained DNA in Dasysiphonia chejuensis Lee et West (Rhodophyta) by a video interfaced digital image processor. The Korean Journal of Phycology 9 (1): 21-28.

Coll J \& EC de Oliveira Filho. 1977. Chromosome counting on 79-year-old dried seaweed, Porphyra leucosticta (Rhodophyta). Experientia 33: 102.

Godward MBE. 1966. The Chromosomes of the Algae, 212 pp. Edward Arnold Publishers Ltd., London.

Goff LJ \& AW Coleman. 1987. The solution to the cytological paradox of isomorphy. The Journal of Cell Biology 104: 739-748.

Goff LJ \& AW Coleman. 1990. DNA: microspectrofluorometric studies. In: Coll KM \& RG Sheath (eds), Biology of the Red Algae 2: 43-71. Cambridge University Press, Cambridge.

González A \& G Collantes. 2001. Taxonomía numérica en la estimación de la diversidad de Porphyra spp. In: Alveal K \& T Antezana (eds), Sustentabilidad de la biodiversidad, un problema actual. Bases científico-técnicas, teorizaciones y proyecciones, pp. 125-137. Universidad de Concepción, Concepción.

Jackson R. 1971. The karyotype in systematics. Annual Review of Ecology and Systematics 2: 327-368.

Kapraun DF \& DW Freshwater. 1987. Karyological studies of five species of Porphyra (Bangiales, Rhodophyta) from the North Atlantic and Mediterranean. Phycologia 26(1): 82-87.

Kapraun DF, TK Hinson \& AJ Lemus. 1991. Karyology and cytophotometric estimation of inter - and intraspecific nuclear DNA variation in four species of Porphyra (Rhodophyta). Phycologia 30(5): 458-466.

Krishnamurthy V. 1984. Chromosome number in Porphyra Agardh. Phykos 23(1-2): 185-190.

Lindstrom SC \& KM Cole. 1992a. Relationships between some North Atlantic and North Pacific species of Porphyra (Bangiales, Rhodophyta): evidence from isozymes, morphology and chromosomes. Canadian Journal of Botany 70(7): 1355-1363.

Lindstrom SC \& KM Cole. 1992b. The Porphyra lanceolata$P$. pseudolanceolata (Bangiales, Rhodophyta) complex unmasked: recognition of new species based on isozymes, morphology, chromosomes and distribution. Phycologia 31(5): 431-448. 
Mumford TF \& K Cole. 1977. Chromosome numbers for fifteen species in the genus Porphyra (Bangiales, Rhodophyta) from the west coast of North America. Phycologia 16(4): 373-377.

Ramírez ME \& B Santelices. 1991. Catálogo de las algas marinas bentónicas de la costa temperada del Pacífico de Sudamérica. Monografías Biológicas. Facultad de Ciencias Biológicas. Pontificia Universidad Católica de Chile $\mathrm{N}^{\circ} 5$ : 1-437.

SERNAPESCA. 2006. Anuario Estadístico de Pesca 2005. 55 pp. Servicio Nacional de Pesca, Valparaíso.

Wilkes RJ, C Yarish \& GG Mitman. 1999. Observations on the chromosome numbers of Porphyra (Bangiales,
Rhodophyta) populations from Long Island Sound to the Canadian Maritimes. Algae 14(4): 219-222.

Wittmann W. 1965. Aceto-iron-haematoxylin-chloral hydrate for chromosome staining. Stain Technology 40:161-164.

Yabu H \& J Tokida. 1963. Mitosis in Porphyra. Bulletin of the Faculty of Fisheries, Hokkaido University 14(3): 131149.

Yabu H. 1975. Cytological studies in the Rhodophyta and Chlorophyta. In: Tokida J \& H Hirose (eds). Advance of Phycology in Japan, pp. 125-135. Dr. W Junk B. V. Publishers, The Hague.

Recibido el 8 de agosto de 2007 y aceptado el 8 de noviembre de 2007 